\title{
Sistem Informasi Pemesanan Laundry Berbasis Android Di Kota Palembang
}

\author{
Evan Susanto ${ }^{* 1}$, Tri Hartati Utami ${ }^{2}$, Dedy Hermanto ${ }^{3}$ \\ ${ }^{1,2}$ STMIK GI MDP, ${ }^{3}$ AMIK MDP; Jl. Rajawali No. 14 Palembang, +62 (711) 376400 \\ ${ }^{1,2,3}$ Program Studi Sistem Informasi, ${ }^{3}$ Teknik Komputer, Palembang \\ e-mail: *1evan96@mhs.mdp.ac.id, ${ }^{2}$ trihartatiutami@mhs.mdp.ac.id, ${ }^{3}$ dedy@mdp.ac.id
}

\begin{abstract}
Abstrak
Laundry adalah fasilitas dimana pakaian dicuci dan dikeringkan. Laundry biasa menggunakan mesin cuci otomatis yang disebut sebagai landromat atau merk dagang umum. Dengan perkembangan model busana dan berbagai jenis perlengkapan lainnya membuat usaha jasa laundry juga meningkat, tetapi semakin meningkat nya jumlah usaha jasa laundry juga berarti meningkatnya persaingan. Hal ini membuat pemilik usaha laundry baik yang sudah lama beroperasi ataupun yang baru mulai kesulitan mencari calon pelanggan dan juga mempromosikan usahanya, di lain sisi bagi pelanggan atau calon pelanggan juga mengalami kesulitan mencari jasa laundry yang memiliki kualitas terbaik. Maka dari itu penulis berniat untuk membuat Sistem Informasi Pemesanan Laundry Berbasis Android di Kota Palembang. Proses pengembangan sistem informasi ini menggunakan metode Rational Unified Process (RUP). Pada tahap analisis digunakan PIECES dan Usecase Diagram. Pada tahap perancangan menggunakan Class Diagram. Pengembangan aplikasi menggunakan Bahasa pemrograman Java dan MySQL sebagai basis datanya. Hasil dari pengembangan sistem adalah dapat membantu Pemilik jasa laundry untuk mempromosikan usahanya serta dapat mempermudah pelanggan dalam mencari tempat laundry terdekat dengan kualitas terbaik.
\end{abstract}

Kata kunci: Pelayanan Laundry, SIG, Kota Palembang, Android, RUP (Unified process), XML, Java, PHP, dan MySQL.

\begin{abstract}
Laundry is a facility where clothes are washed and dried. Laundry usually uses an automatic washing machine called laundromat or a general trademark. With the development of fashion models and various other types of equipment make the laundry service business increased, but the increasing number of laundry services business also means increased competition. This makes laundry business owners both those who have long been operating or those who are just starting to have trouble finding prospective customers and also promoting their business, on the other hand for customers or prospective customers also have difficulty finding laundry services that have quality services and desired criteria. Therefore, the author intends to make an Android-Based Laundry Ordering Information System in Palembang City. The process of developing this information system uses the Rational Unified Process (RUP) method. The author also use PIECES and Usecase Diagram in the analysis phase. At the design stage using Class Diagrams. Application development using the Java programming language and MYSQL as database. This information system is expected to be able to help laundry service business owners in overcoming problems that often occur in running their business processes, and also to facilitate prospective customers in looking for laundry services they want.
\end{abstract}

\section{Keywords:}

Laundry, Geographic Information System, Palembang, Android, Rational Unified Process Methodology, java, PHP and MYSQL 


\section{PENDAHULUAN}

A ndroid merupakan salah satu smartphone yang perkembangannya sangat pesat, di Indonesia sendiri penggunaan smartphone semakin meningkat dari tahun ke tahunnya, tetapi tidak banyak orang yang benar-benar memanfaatkan smartphone secara maksimal. Kebanyakan orang hanya menggunakannya untuk sosial media dan hiburan semata. Berbicara tentang sosial media, sosial media atau yang sering disingkat menjadi sosmed adalah sebuah media untuk bersosialisasi satu sama lain dan dilakukan secara online yang memungkinkan manusia untuk berinteraksi tanpa dibatasi ruang dan waktu. Sosial media saat ini tidak hanya berfungsi sebagai media untuk berkomunikasi saja, banyak penggunanya juga membuka peluang usaha melalui sosial media, mulai dari menjual barang seperti pakaian, case handphone, dan peralatan rumah, dan untuk jasanya banyak penggunanya yang menjual jasa seperti jasa service elektronik, jasa pijat urut dan jasa cuci laundry.

Dengan semakin berkembangnya zaman, gaya hidup serta tuntutan hidup yang meningkat membuat pola pikir masyarakat kota juga berubah. Pegawai, siswa, serta mahasiswa yang disibukkan dengan rutinitas pekerjaan sehingga mereka tidak memiliki waktu untuk mencuci pakaian terutama yang tinggal sendirian atau kos lebih banyak menghabiskan waktu di luar rumah, sehingga tidak memiliki banyak waktu untuk melakukan tugas mencuci dan menyetrika, dikarenakan hal tersebut Jasa Laundry merupakan pilihan yang tepat untuk menggantikan mereka dalam melakukan kegiatan yang tidak dapat mereka lakukan sendiri. Kondisi ini oleh sebagian orang dimanfaatkan untuk membuka usaha bisnis laundry dan memperoleh penghasilan. Menurut Badan Penanaman Modal dan Pelayanan Terpadu Satu Pintu Kota Palembang, pada tahun 2017 yang tercatat ada sekitar-251 usaha jasa laundry di Kota Palembang, dengan maraknya usaha laundry membuat masyarakat menjadi selektif untuk memilih tempat laundry dengan kualitas terbaik dan dekat dengan tempat tinggal.

\section{LANDASAN TEORI}

\subsection{Sistem Informasi}

Sistem informasi adalah suatu sistem yang terdapat di dalam suatu organisasi yang mempertemukan kebutuhan pengolahan transaksi harian yang mendukung fungsi operasi organisasi yang bersifat manajerial dengan kegiatan strategi dari suatu organisasi untuk dapat menyediakan laporan-laporan yang di perlukan oleh pihak luar tertentu [5].

\subsection{Use Case}

Use case diagram merupakan pemodelan untuk kelakukan sistem informasi yang akan dibuat. Use case menjelaskan interaksi antara satu aktor atau lebih dengan sistem informasi yang akan dibuat. Use case biasanya digunakan untuk mengetahui fungsi apa saja yang ada di dalam sebuah sistem informasi dan siapa saja yang berhak menggunakan fungsi-fungsi itu [2].

\subsection{Activity Diagram}

Dalam diagram aktivitas atau activity diagram menggambarkan aliran kerja atau aktivitas dari sebuah sistem. Yang harus diperhatikan bahwa pada diagram aktivitas menggambarkan aktivitas yang sistem kerjakan bukan apa yang dilakukan actor [2]. 


\subsection{Sequence Diagram}

Sequence Diagram atau diagram sekuen menjelaskan kelakukan objek pada use case diagram dengan menjelaskan waktu hidup proyek dan pesan yang dikirimkan dan diterima antar objek. Oleh karena itu, dalam proses penggambarannya harus diketahui objek-objek yang terlibat dalam sebuah use case beserta metode-metode yang dimiliki kelas yang diinstansiasi menjadi suatu objek [2].

\subsection{Sistem Informasi Geografis}

Sistem Informasi Geografis (SIG) merupakan tiga unsur pokok yang terdiri dari: sistem, informasi dan geografis. Sistem Informasi Geografis juga merupakan salah satu tipe sistem informasi tetapi dengan tambahan unsur geografis "informasi geografis". "Geografis" merupakan bagian dari spasial (keruangan) Kedua istilah ini sering digunakan secara bergantian atau bahkan tertukar satu sama lainnya hingga muncullah istilah yang ketiga "geospasial". Dengan demikian, istilah "informasi geografis" mengandung pengertian informasi mengenai lokasi yang terletak di permukaan bumi, pengetahuan mengenai posisi dimana suatu objek terletak di permukaan bumi, atau informasi mengenai keterangan-keterangan objek penting yang terdapat di permukaan bumi yang posisinya diberikan atau diketahui [4].

\subsection{Rational Unified Process (RUP)}

Rational Unified Process atau biasa disingkat RUP merupakan suatu pendekatan pengembangan perangkat lunak yang dilakukan secara berulang-ulang (iterative), fokus pada arsitektur (architecture-centric), dan lebih diarahkan berdasarkan kasus yang digunakan (use case driven). RUP merupakan proses rekayasa perangkat lunak dengan pendefinisian yang baik (well defined) dan dengan struktur yang baik (well structured) [2].

\subsection{Android}

Android merupakan sistem operasi untuk perangkat mobile yang mencakup sistem operasi aplikasi. Android menyediakan platform terbuka bagi para pengembang untuk menciptakan aplikasi mereka. Saat ini sebagian besar vendor-vendor smartphone sudah memproduksi smartphone berbasis android. Hal ini, dikarenakan android adalah sistem operasi yang open source sehingga bebas dipakai oleh vendor manapun [3].

\section{$2.8 \quad M y S Q L$}

MySQL merupakan software yang tergolong database server dan bersifat open source yang berarti software ini dilengkapi dengan source code (kode yang dipakai untuk membuat $M y S Q L)$. MySQL dapat dijalankan pada berbagai sistem operasi [1].

\section{HASIL DAN PEMBAHASAN}

\subsection{Analisis Permasalahan}

Analisis permasalahan menggunakan kerangka PIECES yang terdiri dari Performance, Information, Economics, Control, Eficiency, dan Service. Hasil analisis adalah sebagai berikut.

1. Performance

Komplain dari konsumen mengenai kualitas hasil cuci yang kurang memuaskan dikarenakan belum mengetahui riwayat kinerja laundry tersebut. 


\section{Information}

Informasi mengenai tarif harga, kualitas jasa cuci laundry serta pelayan dan juga lokasi yang sulit didapatkan kecuali mesti datang sendiri, tapi dengan adanya aplikasi ini calon pelanggan dapat melihat hal tersebut.

\section{Economics}

Banyak pemilik laundry kesulitan mempromosikan usahanya dan mencari calon pelanggan.

\section{Control}

Catatan pesanan terkadang hilang sehingga petugas laundry perlu menghubungi pelanggan untuk konfirmasi.

\section{Eficiency}

Pelanggan harus datang ke tempat cuci laundry terlebih dahulu untuk mengetahui harga serta informasi mengenai laundry.

6. Services

Layanan yang kurang memuaskan seperti masalah kebersihan, kerapihan dan masalah

ketepatan waktu penyelesaiannya.

\subsection{Analisis Kebutuhan}

Pada analisis kebutuhan ini dapat diuraikan kebutuhan fungsional dan kebutuhan nonfungsional dari sistem yang akan dibangun.

\subsection{Kebutuhan Fungsional}

Use case diagram merupakan suatu permodelan untuk mendeskripsikan kebutuhan sistem terutama aktor yang akan menggunakan sistem, sehingga segala persyaratan sistem yang baik dapat tergambarkan. Dengan teknik use case, fungsi dapat digambarkan apa saja yang ada di dalam sistem dan siapa saja user yang berhak menggunakan sistem tersebut. Use case diagram pada Sistem Informasi Pemesanan Jasa Laundry di Kota Palembang dapat dilihat pada Gambar 1.

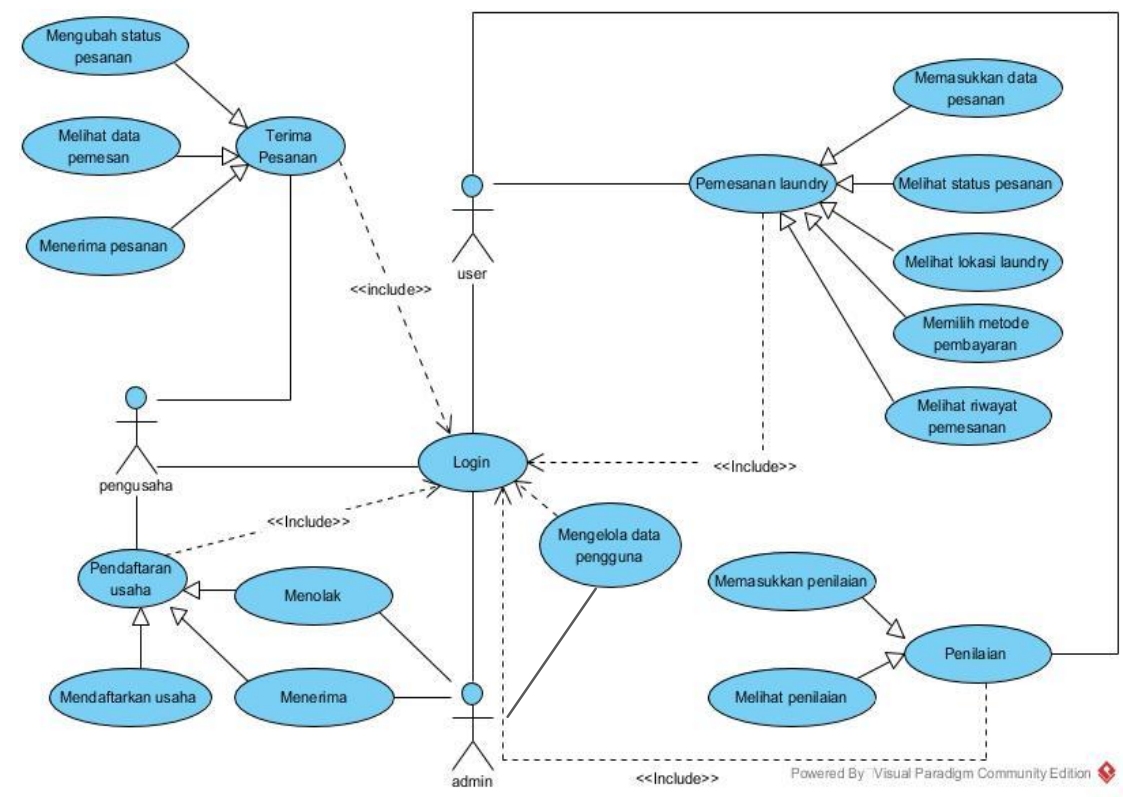

Gambar 1. Use Case Diagram 
Use case diagram yang dirancang pada Sistem Informasi Pemesanan Jasa Laundry di Kota Palembang terdiri dari tiga aktor yaitu Pemilik usaha, Admin dan Pelanggan. Use case diagram terdiri dari jumlah use case yang memiliki hubungan generalisasi dan spesialisasi.

\subsection{Kebutuhan Non Fungsional}

Kebutuhan non fungsional yang ada pada sistem adalah sebagai berikut sebagai berikut:

1) Operasional

Perangkat keras yang digunakan pada sistem ini membutuhkan smartphone android dan juga internet yang terhubung kewebsite serta software sebagai database.

Aplikasi pendukung yang digunakan untuk mendukung berjalannya sistem ini adalah Telepon dan Map.

2) Informasi

Pengguna dapat mengakses informasi mengenai lokasi, harga, penilaian serta jasa pelayanan yang ditawarkan oleh pengusaha.

3) Kinerja

Waktu yang dibutuhkan saat melakukan pencarian usaha laundry akan lebih cepat.

4) Keamanan

Sistem ini dilengkapi dengan adanya username dan juga password untuk membedakan antara pengguna satu dan lainnya.

\subsection{Rancangan Sistem}

Pada tahap ini, rancangan sistem dibuat menggunakan Class Diagram, Activity Diagram, Sequence Diagram dan tampilan antar muka aplikasi.

\subsubsection{Class Diagram}

Diagram kelas merupakan diagram yang menggambarkan struktur sistem dari segi pendefinisan kelas-kelas yang akan dibuat untuk membangun sistem. Kelas memiliki apa yang disebut atribut dan metode [2]. Class Diagram yang diusulkan pada sistem dapat dilihat pada Gambar 2.

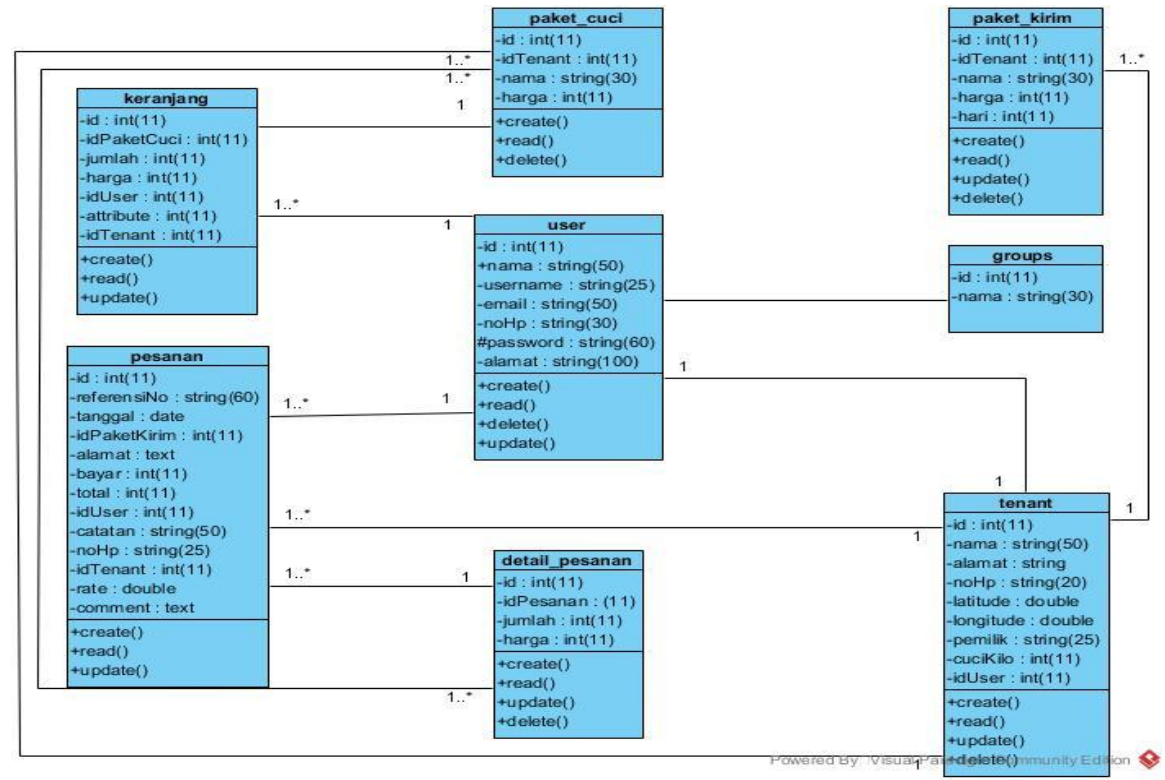

Gambar 2. Class Diagram yang Diusulkan 


\subsubsection{Activity Diagram}

Activity diagram merupakan diagram yang akan menjabarkan aliran kerja atau aktivitas dari sistem berdasarkan Use case Diagram. Dimana dalam pembuatan sebuah activity diagram bisa berasal dari beberapa use case. Berikut ini adalah activity diagram untuk Login, Pemesanan Laundry dan Penilaian.

\subsubsection{Activity Diagram Login}

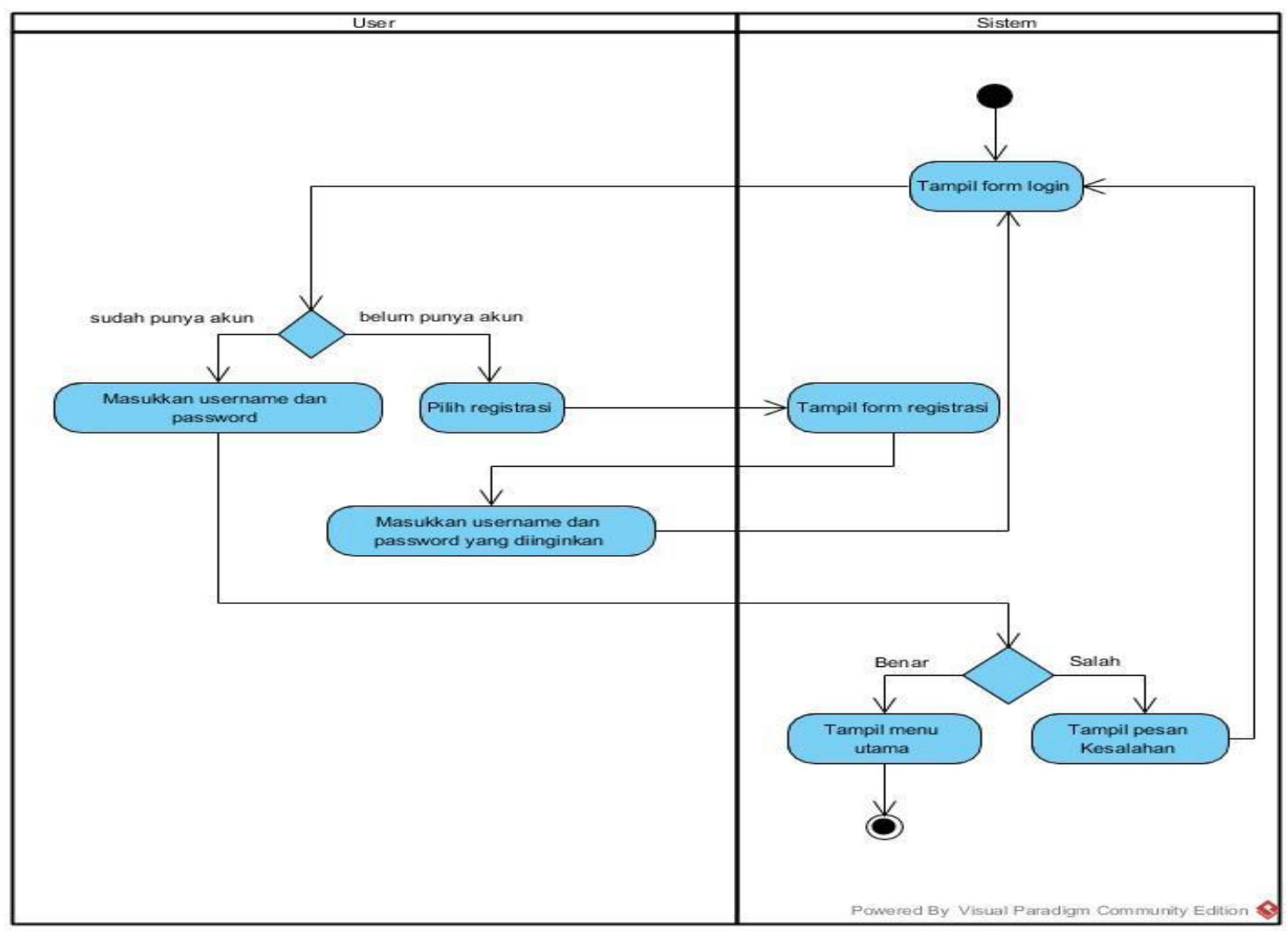

Gambar 3. Activity Diagram Login

Pada Gambar 3 Activity Diagram Login menggambarkan pengguna harus login terlebih dahulu sebelum dapat mengakses aplikasi, bagi pengguna yang tidak memiliki hak akses otomatis tidak dapat masuk kedalam aplikasi. Jika pengguna salah memasukkan ID ataupun password maka akan tampil pesan peringatan bahwa pengguna salah memasukkan ID atau password. 


\subsubsection{Activity Diagram Pemesanan Laundry}

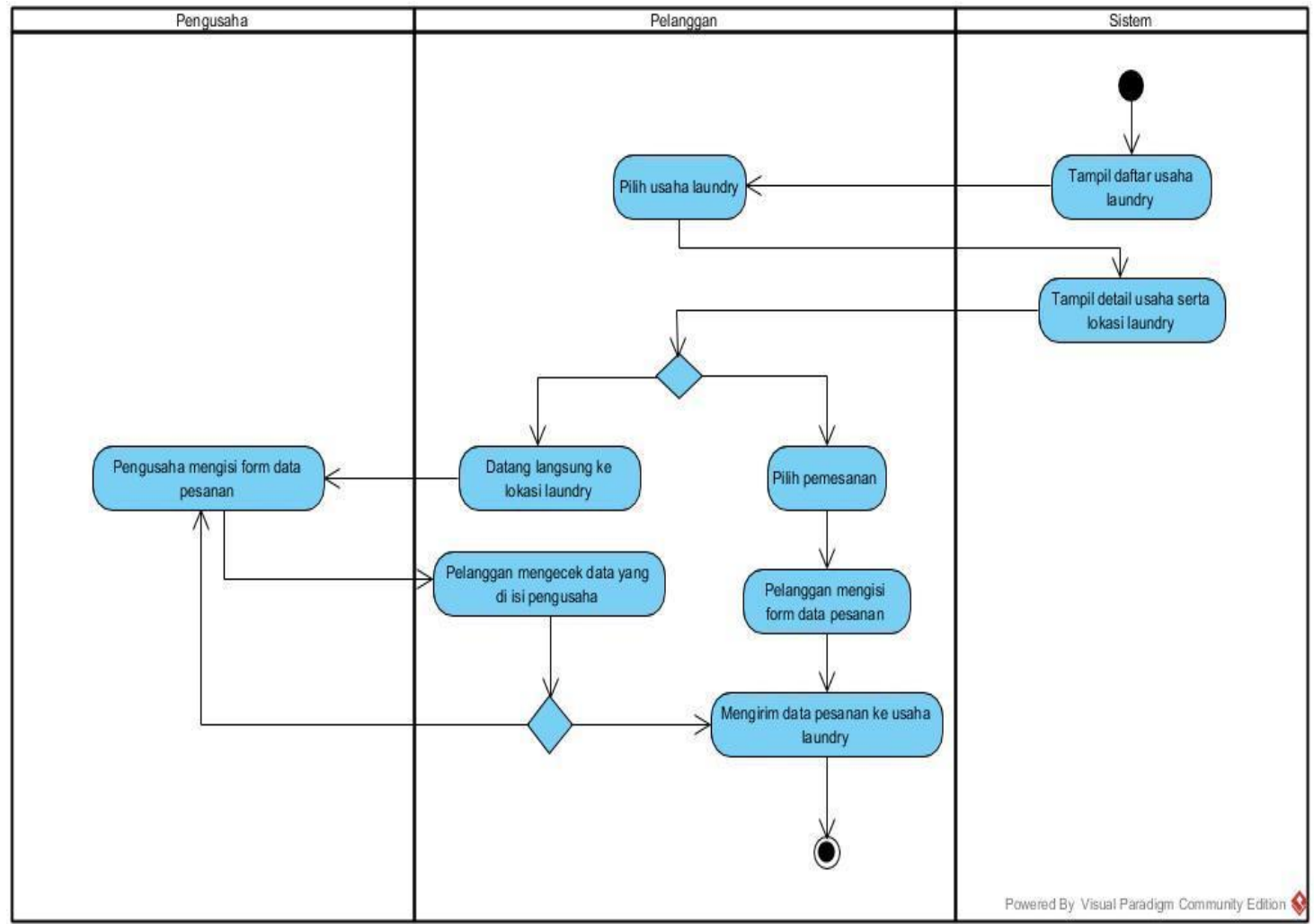

Gambar 4. Activity Diagram Memasukkan Data Pesanan

Pada Gambar 4 menjelaskan mengenai pemesanan laundry dimana user memilih usaha laundry yang sesuai dengan jarak dan kualitas yang diinginkan Kemudian user memasukkan data pesanan dan memilih jasa yang ditawarkan oleh pengusaha laundry, atau pelanggan juga bisa datang langsung ke lokasi laundry. 


\subsubsection{Activity Diagram Memberikan dan Melihat Penilaian}

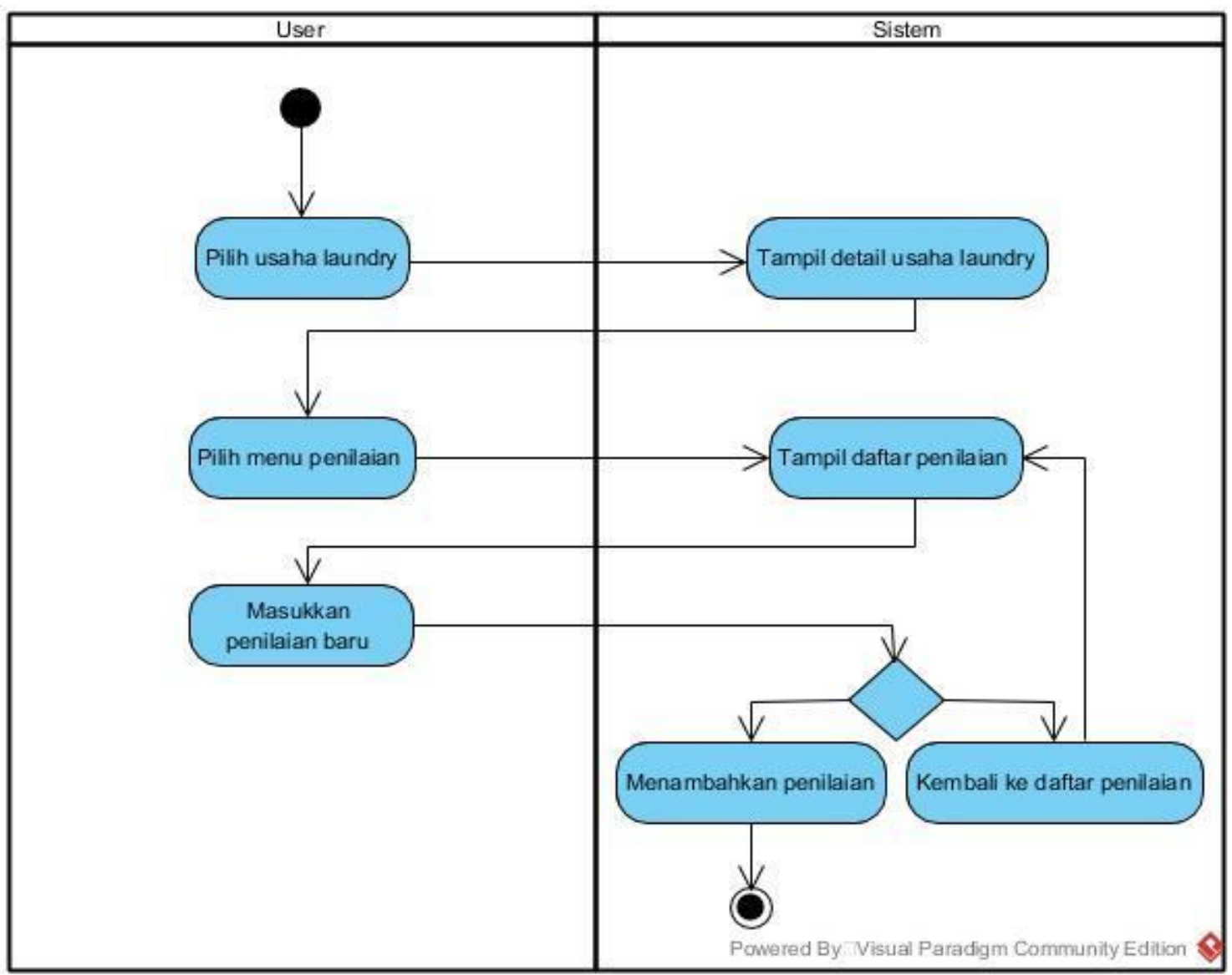

Gambar 5. Activity Diagram Memberikan dan Melihat Penilaian

Pada Gambar 5 Activity Diagram Memberikan dan Melihat Penilaian menggambarkan user mengisi form penilaian terhadap pelayanan yang diberikan oleh usaha laundry serta melihat penilaian yang telah diberikan oleh user lain mengenai kualitas pelayan usaha laundry yang dipilih. User hanya dapat mengisi form penilaian jika sudah melakukan transaksi dengan usaha laundry tersebut paling tidak satu kali. Sedangkan Untuk dapat melihat penilaian, User tidak harus melakukan transaksi terlebih dahulu.

\subsection{Relasi Antar Tabel}

Pada tahap ini dibuat Relasi antar tabel untuk merancang database. Relasi antar tabel adalah pemodelan awal yang dikembangkan berdasarkan teori himpunan dalam bidang metematika untuk pemodelan basis data relasional [4]. 


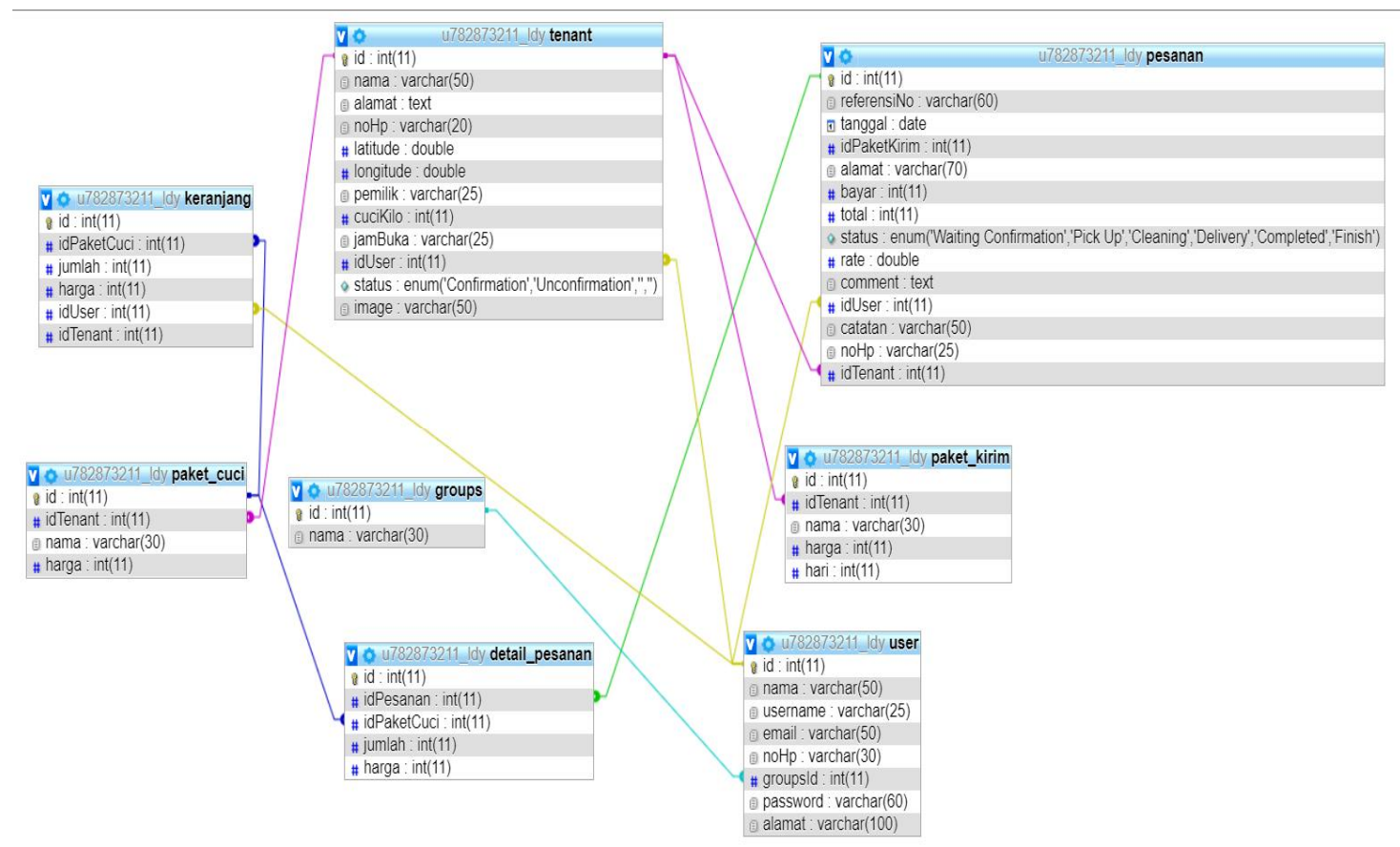

Gambar 6. Relasi Antar Tabel yang Diusulkan

\subsection{Tampilan Aplikasi}

Aplikasi mobile Pemesanan Laundry Palembang merupakan Aplikasi mobile yang bersifat online harus terhubung dengan internet. Tampilan Aplikasinya dapat dilihat pada sampai dengan Gambar 9. Gambar 7 Interface Login menggambarkan tampilan awal saat user ingin melakukan login. Halaman ini dapat diakses dengan cara menekan menu drawer kemudian pilih login, bagi pengguna yang belum mempunyai akun dapat melakukan registrasi dengan cara menekan tombol registrasi nantinya akan muncul form pengisian data.

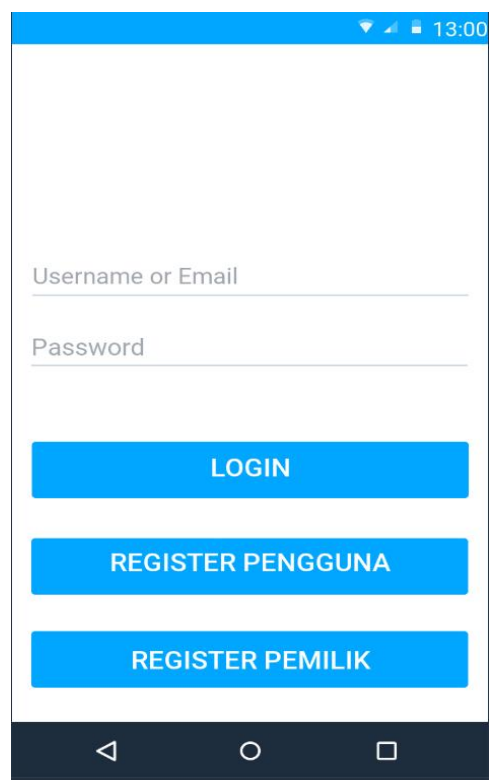

Gambar 7. Interface Halaman Login 
Pada Gambar 8 Interface Form Pengisian Pesanan menjelaskan setelah user menekan tombol order maka sistem akan menampilkan form pesanan, dalam form ini user diharuskan mengisi data dengan lengkap dan benar sehingga tidak terjadi kesalahan yang nantinya akan menyebabkan pengusaha laundry kesulitan dalam proses pengerjaan. Setelah selesai mengisi form kemudian user menekan tombol pesan maka data pesanan akan diterima oleh pengusaha jasa laundry. Jika user memilih untuk datang langsung ke lokasi jasa laundry, maka pemilik jasa laundry yang mengisi form pesanan yang nantinya akan dikonfirmasi oleh user.

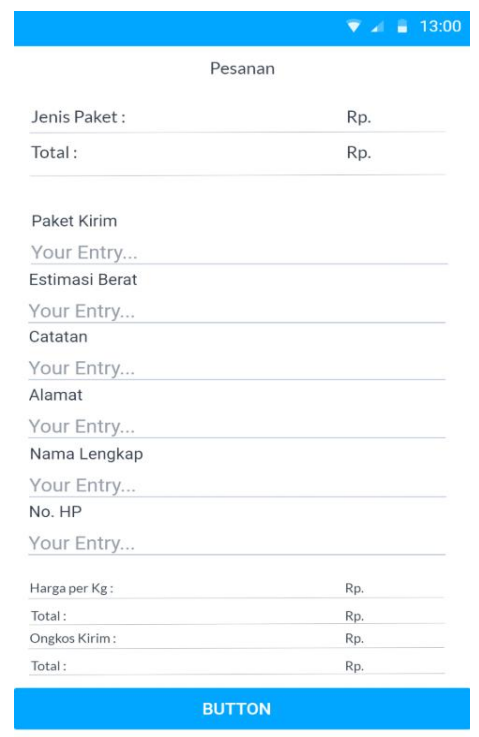

Gambar 8. Interface Form Pengisian Pesanan

Gambar 9 Rancangan Antar Muka Halaman Penilaian menggambarkan penilaian yang telah diberikan oleh pelanggan kepada pengusaha laundry setelah pelanggan menggunakan jasanya.

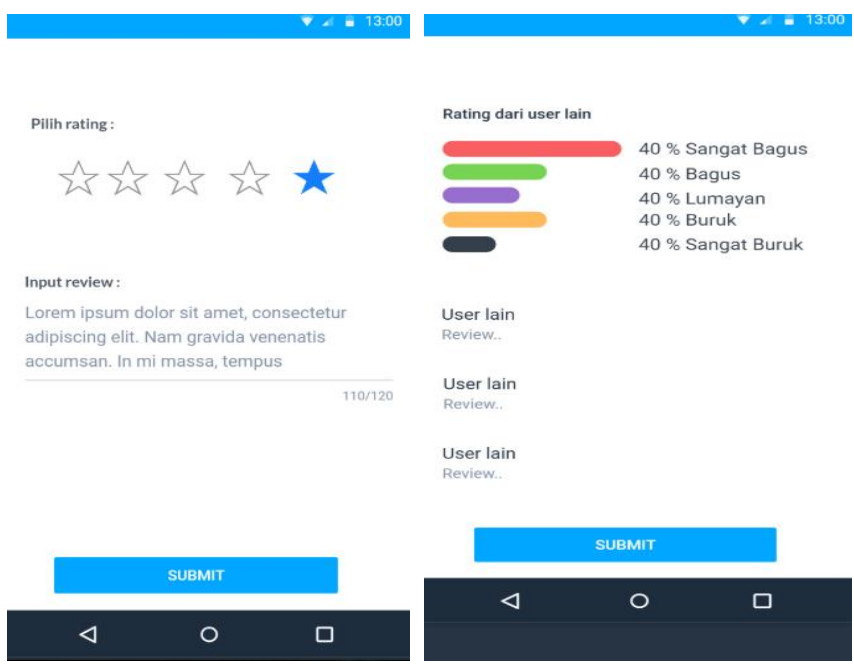

Gambar 9. Interface Form Penilaian 


\section{KESIMPULAN} berikut:

Berdasarkan hasil yang telah diuraikan sebelumnya, dapat ditarik kesimpulan sebagai

1. Sistem ini memiliki fitur penilaian sehingga pemilik usaha dapat mempermudah melakukan promosi dan meningkatkan kualitas usahanya.

2. Sistem ini dapat mempermudah pelanggan dalam mencari tempat laundry terdekat dengan kualitas terbaik berdasarkan dari hasil penilaian.

\section{SARAN}

Berdasarkan hasil analisis dan pembahasan yang telah dilakukan, Peneliti selanjutnya diharapkan dapat mengembangkan sistem ini seiring dengan berkembangnya spesifikasi kebutuhan pengguna dan Perlunya melakukan maintanence secara berkala untuk menghindari kehilangan data.

\section{DAFTAR PUSTAKA}

[1] Abdul, Kadir. 2011, Pengertian PHP, Tersedia Dalam: Buku Pintar Programer Pemula PHP, Yogyakarta, Mediakom.

[2] A.S, Rosa dan M Shalahuddin. 2013, Rekayasa Perangkat Lunak Terstruktur dan Berorientasi Objek, Informatika, Bandung.

[3] Nazruddin, Safaat. 2012, ANDROID: Pemrograman Aplikasi Mobile Smartphone dan Tablet PC Berbasis Android, Informatika, Bandung.

[4] Prahasta, Eddy. 2009, Sistem Informasi Geografis Konsep-Konsep Dasar, Informatika, Bandung.

[5] Sutabri Tata. 2012, Analisis Sistem Informasi, Andi Offset, Yogyakarta. 